\title{
Sod Production on a Solid-waste Compost over Plastic
}

\author{
John L. Cisar \\ Fort Lauderdale Research and Education Center, University of Florida, \\ Institute of Food and Agricultural Sciences, 3205 S. W. College Avenue, \\ Fort Lauderdale, FL 33314 \\ George H. Snyder \\ Everglades Research and Education Center, University of Florida, \\ Institute of Food and Agricultural Sciences, Belle Glade, FL 33430 \\ Additional index words. Stenotaphrum secundatum, Cynodon transvaalensis $\times C$. \\ dactylon, Paspalum notatum, turfgrass, fertilization
}

\begin{abstract}
The objective of this experiment was to determine the suitability of a compost obtained from a commercially available solid-waste processing plant for sod production when placed over a plastic barrier. Comparisons were made between compostgrown sod with and without fertilizer and between compost-grown sod and commercially grown sod. Six weeks after seeding or sprigging, both fertilized and nonfertilized compost-grown 'Argentine' bahiagrass (Paspalum notatum Flugge), 'Tifway' bermudagrass (Cynodon transvaalensis $\times$ C. dactylon), and 'Floratam' St. Augustinegrass [Stenotaphrum secundatum (Walt.) Kuntze.] had discolored leaf blade tissue and poor growth. At 6 weeks, bahiagrass leaf tissue had a low $\mathbf{N}$ concentration, which suggested that the compost immobilized fertilizer $N$. Additionally, initial high salinity of the compost $\left(2.85 \mathrm{dS} \cdot \mathrm{m}^{-1}\right)$ may have contributed to turf discoloration and lack of vigor. However, poor growth and discoloration were temporary. At 3 and 5 months, fertilized compost-grown turfgrasses had higher quality and coverage than nonfertilized sod. At 5 months, fertilized sod had sufficient coverage for harvest, whereas for conventional field production 9 to 24 months generally is required to produce a harvestable product. Compost-grown sod pieces had similar or higher tear resistance than commercially grown sod. One and 3 weeks after transplanting on a sand soil, compost-grown sod produced higher root weight and longer roots in the underlying soil than did commercially grown sod. The solid-waste compost used in this study offers a viable alternative material for producing sod that will benefit solid-waste recycling efforts.
\end{abstract}

Sod production is a major horticultural industry in Florida with $>22,000$ ha in production and $>15,000$ ha harvested annually (Cisar et al., 1988). Nearly 50\% of this hectarage is St. Augustinegrass grown on shallow muck soils in southern Florida (Cisar et al., 1992; Neel et al., 1978). Soil subsidence via oxidation and soil removal after harvesting are decreasing the productivity and depth of muck soils (Neel et al., 1978). Sod production could use large quantities of solid-

Received for publication 13 Feb. 1991. Accepted for publication 10 Sept. 1991. Contribution from the Florida Agr. Expt. Sta., Florida Expt. Sta. J. Ser. no. R-01285. We gratefully acknowledge the financial support of Agripost and the Florida Pest Control Operators Assn., Region 10, and the technical assistance of K.E.. Williams and E. Green. The cost of publishing this paper was defrayed in part by the payment of page charges. Under postal regulations, this paper therefore must be hereby marked advertisement solely to indicate this fact. waste compost as an end product, thus benefiting recycling efforts, reducing another potential source of waste, and preserving agricultural soils. For example, in Florida quantities of solid waste delivered to all landfills must be reduced $30 \%$ by 1993 (Florida Dept. of Environmental Regulation, 1989). Moreover, sod production on unconsolidated materials placed over a plastic barrier has been proposed to facilitate production and harvesting (Kabbaz et al., 1987; Neel et al., 1978).

The objective of this study was to determine the suitability of a compost obtained from a commercially available solid-waste processing plant for sod production when placed on a plastic barrier.

Agrisoil compost was provided by the manufacturer (Agripost, Pompano Beach, Fla.). The substrate was mixed urban solid waste composted for 21 days in windrows, and the material was allowed to cure inside 
Table 1. Soil test values of compost taken before and 6 weeks after experiment initiation ${ }^{z}$, and total nutrient analysis of bahiagrass leaf blade tissue 6 weeks after experiment initiation.

\begin{tabular}{|c|c|c|c|c|}
\hline \multirow[b]{3}{*}{ Nutrient } & \multicolumn{4}{|c|}{ Nutrient content } \\
\hline & \multicolumn{2}{|c|}{ Compost } & \multicolumn{2}{|c|}{ Leaf blade tissue } \\
\hline & \multicolumn{2}{|c|}{$\left(\mathrm{mg} \cdot \mathrm{kg}^{-1}\right)$} & \multicolumn{2}{|c|}{$\left(\mathrm{g} \cdot \mathrm{kg}^{-1}\right)$} \\
\hline $\mathrm{N}$ & 56 & 6 & 10 & 9 \\
\hline $\mathrm{P}$ & 3 & 6 & 2 & 3 \\
\hline K & 229 & 41 & 15 & 14 \\
\hline $\mathrm{Ca}$ & 970 & 2230 & 14 & 18 \\
\hline \multirow[t]{2}{*}{$\mathrm{Mg}$} & 83 & 55 & 1 & 1 \\
\hline & & & \multicolumn{2}{|c|}{$\left(\mathrm{mg} \cdot \mathrm{kg}^{-1}\right)$} \\
\hline $\mathrm{Fe}$ & 16 & 9 & 360 & 550 \\
\hline $\mathrm{Mn}$ & 21 & 25 & 150 & 85 \\
\hline $\mathrm{Cu}$ & 1 & 2 & 23 & 28 \\
\hline $\mathrm{Zn}$ & 23 & 33 & 90 & 110 \\
\hline B & 2 & 1 & -- & --- \\
\hline $\mathbf{S}$ & 236 & 22 & ..- & -.- \\
\hline Soil EC $\left(\mathrm{dS} \cdot \mathrm{m}^{-1}\right)$ & 2.85 & 0.34 & ... & .-- \\
\hline Soil pH & 7.1 & 7.6 & --- & -.- \\
\hline
\end{tabular}

${ }^{2} \mathrm{P}$ was extracted with a strong and weak Bray solution while other nutrients were extracted with a modified Morgan extract. Soluble salts (EC) were determined using a 2 water : 1 soil extract.

Table 2. Visual quality and coverage ratings for compost-grown turfgrass.

\begin{tabular}{|c|c|c|c|c|}
\hline \multirow[b]{2}{*}{ Variable } & \multicolumn{2}{|c|}{ Visual quality } & \multicolumn{2}{|c|}{ Cover $(\%)$} \\
\hline & 9 Aug. & 31 Oct. & 9 Aug. & 31 Oct. \\
\hline \multicolumn{5}{|l|}{ Grass } \\
\hline Bahiagrass & 6.5 & 6.2 & 51 & 72 \\
\hline Bermudagrass & 6.3 & 6.8 & 51 & 77 \\
\hline St. Augustine & 6.0 & 7.2 & 49 & 84 \\
\hline Significance & NS & + & NS & NS \\
\hline \multicolumn{4}{|l|}{ Fertilizer treatment } & -- \\
\hline Fertilizer & 8.0 & 8.9 & 76 & 99 \\
\hline No fertilizer & 4.6 & 4.7 & 25 & 57 \\
\hline Significance & ** & $* *$ & ** & ** \\
\hline Grass $\times$ fertilizer & & & & \\
\hline interaction & NS & NS & NS & NS \\
\hline
\end{tabular}

${ }_{* *,+, N S} P<0.01,0.10$, and $P>0.10$, respectively.

Table 3. Comparison of sod tear resistance between compost-grown and commercially grown turfgrasses on 31 Oct. 1990 illustrating the significant $(P<0.10)$ grass $\times$ method interaction.

\begin{tabular}{llc}
\hline \hline Grass & \multicolumn{1}{c}{ Method } & $\begin{array}{c}\text { Tear resistance } \\
(\mathrm{kg})\end{array}$ \\
\hline Bahiagrass & Compost over plastic & 21.4 \\
& Commercially grown & 25.8 \\
Bermudagrass & Compost over plastic & 39.4 \\
& Commercially grown & 41.8 \\
St. Augustinegrass & Compost over plastic & 45.1 \\
& Commercially grown & 35.6 \\
$\mathrm{LSD}_{0.05}$ & & 8.7 \\
\hline
\end{tabular}

a warehouse for 3 months before use. Preprocessing procedures included removal of hazardous and toxic materials by hand removal of batteries, large appliances, and other large bulky items. Glass and plastic bottles and small metallic components, such as metal cans, were crushed and included in the compost. Postprocessing of the compost included screening through 6-mm sieves. The material qualified as Florida Dept. of Regulation Code 1 material in regard to heavy metal content with $\mathrm{Cd}<15, \mathrm{Cu}<450, \mathrm{~Pb}<500$, $\mathrm{Ni}<50$, and $\mathrm{Zn}<900 \mathrm{mg} \cdot \mathrm{kg}^{-1}$ (ICF, 1990). Routine soil test nutrient and chemical analyses of the compost were conducted by A \& L Southern Agricultural Laboratories, Pom-
Florida. Grass main plots were $1 \times 6 \mathrm{~m}$ and fertilizer subplots were $1 \times 3 \mathrm{~m}$. Bahiagrass seeds were sown at a rate of $100 \mathrm{~kg} \cdot \mathrm{ha}^{-1}$. St. Augustinegrass and bermudagrass were sprigged on 0.25 -m centers. Establishmentperiod ( 3 weeks) irrigation was applied three times a day to provide a total of $125 \%$ of daily predicted (McCloud, 1955) evapotranspiration $(\approx 2.5 \mathrm{~mm} /$ application in May) to avoid water stress. Thereafter, irrigation was applied once daily at a rate of $2.5 \mathrm{~mm} \cdot$ day $^{-1}$. St. Augustinegrass and bahiagrass were mowed at a height of $5 \mathrm{~cm}$, while bermudagrass was mowed at a height of $2.5 \mathrm{~cm}$. No pesticides were applied during this experiment.

To evaluate the compost's potential for providing a source of nutrients, the turfgrasses were grown with and without fertilizer. A complete fertilizer (16N-1.8P-6.6K), which included several secondary and micronutrients (1.2 Mg, 0.03 B, 0.09 Cu, 1.3 $\mathrm{Fe}, 0.4 \mathrm{Mn}, 13.3 \mathrm{~S}$, and $0.08 \mathrm{Zn}$ ), was applied biweekly to supply $5 \mathrm{~g} \mathrm{~N} / \mathrm{m}^{2}$ A nutrient analysis using previously described methods (Snyder et al., 1989) was conducted on bahiagrass leaf blade tissue harvested 6 weeks after sowing from fertilized and nonfertilized plots to determine whether poor growth and color of bahiagrass were related to either nutritional deficiency or toxicity.

On 9 Aug. 1990 and 31 Oct. 1990, turfgrasses were rated visually for percent ground cover and turfgrass quality ( 1 to 10 , with 10 $=$ best quality, $1=$ dead or brown turf, and $6=$ minimal acceptable quality).

On 31 Oct. 1990 , a $0.3 \times 0.45-\mathrm{m}$ sod piece was harvested from each plot that had been fertilized. Tear resistance (the force required to tear a piece of sod into two pieces) of each sod piece was determined for the compost-over-plastic-grown and commercially grown sods using a device patterned after that described by Beard and Rieke (1969). The commercially grown St. Augustinegrass was produced on a muck soil, and bermudagrass and bahiagrass were produced on mineral (sand) soils.

Compost-grown and commercially grown sod pieces were then evaluated for rooting into sand soil. Sod pieces were placed on Margate fine sand (Siliceous, hyperthermic Mollic Psamnaquent). Irrigation was provided three times a day $(2.5 \mathrm{~mm} / \mathrm{application})$ to avoid water stress. One and 3 weeks after transplanting, root weights and root lengths were determined in 10 -cm-diameter $\times 20$ cm-deep soil cores (two per plot) removed from the sand soil underneath the sod pieces. The sod was separated from the soil core at the sand soil surface. The soil cores were rinsed to separate roots from soil. Roots were then dried at $70 \mathrm{C}$ and weighed.

For visual quality and percent cover ratings, we used a split plot with six replications per treatment. Grasses were the main plots and fertilizer treatments were the subplots. Sod tear resistance, sod root weight, and sod root length were evaluated as a completely randomized design. Data were subjected to analysis of variance (ANOVA) procedures (SAS, 1985), and significant 
Table 4. Root weights and root lengths of transplanted sod at 1 and 3 weeks following harvest.

\begin{tabular}{|c|c|c|c|c|c|}
\hline \multirow[b]{2}{*}{ Variable } & & \multicolumn{2}{|c|}{ Root wt (g) } & \multicolumn{2}{|c|}{ Root length $(\mathrm{cm})$} \\
\hline & & $1 \mathrm{wk}$ & 3 wk & $1 \mathrm{wk}$ & $3 \mathrm{wk}$ \\
\hline \multicolumn{6}{|l|}{ Grass } \\
\hline Bahia & & 0.14 & 0.47 & 5.73 & 10.54 \\
\hline Bermuda & & 0.06 & 0.31 & 7.71 & 10.91 \\
\hline St. Augustine & & 0.12 & 0.17 & 4.63 & 10.75 \\
\hline Significance & & + & $* *$ & $* *$ & NS \\
\hline $\operatorname{LSD}_{0.05}$ & & 0.07 & 0.11 & 1.38 & 1.01 \\
\hline \multicolumn{6}{|l|}{ Production method } \\
\hline Compost over plastic & & 0.14 & 0.45 & 6.99 & 11.53 \\
\hline Commercially grown & & 0.08 & 0.19 & 5.06 & 9.94 \\
\hline Significance & & $*$ & $* *$ & $* *$ & $* *$ \\
\hline $\mathrm{LSD}_{0.05}$ & & 0.06 & 0.09 & 1.13 & 1.01 \\
\hline \multirow{3}{*}{$\begin{array}{l}\text { Grass } \\
\text { Bahia }\end{array}$} & Media source & & & & \\
\hline & Compost & --- & 0.85 & --- & --- \\
\hline & Commercial & $\cdots$ & 0.10 & -- & -- \\
\hline \multirow[t]{2}{*}{ Bermuda } & Compost &.- & 0.29 & --- & $\cdots$ \\
\hline & Commercial & $\cdots$ & 0.34 & -- & $--\cdot$ \\
\hline \multirow[t]{2}{*}{ St. Augustine } & Compost & $\cdots$ & 0.20 & -- & $\ldots$ \\
\hline & Commercial & $\cdots$ & 0.13 & -- & $--\cdot$ \\
\hline \multicolumn{6}{|c|}{ Grass $\times$ method interaction } \\
\hline Significance & & NS & $* *$ & NS & NS \\
\hline $\mathrm{LSD}_{0.05}$ & & $\cdots$ & 0.15 & -- & $--\cdot$ \\
\hline
\end{tabular}

means were separated by L-SD when a significant $\mathrm{F}$ value $(P<0.10)$ was obtained.

Soil test analyses indicated that a wide range of essential nutrients were found in the compost (Table 1). Soluble salts were reported as initially very high $\left(2.85 \mathrm{dS} \cdot \mathrm{m}^{-1}\right.$; Ankerman and Large, 1990). However, soluble salts had decreased by almost $90 \%$ at 6 weeks (Table 1). Additionally, none of the individual elements present in the compost appeared to be at concentrations that were toxic to the grasses (Table 1).

Although nutrients were found in the compost, the addition of fertilizer greatly increased the visual quality and coverage of each turfgrass (Table 2). Turfgrasses provided with the biweekly fertilizer treatment were sufficiently covered (nearly $100 \%$ on 31 Oct. 1990) to warrant harvesting following $\approx 5$ months of growth on compost over black plastic (Table 2). At the same time, nonfertilized compost-grown turf grasses had $<60 \%$ coverage, and their visual quality was unacceptable (Table 2). On 31 Oct. 1990, St. Augustinegrass had slightly higher visual quality than either bahiagrass or bermudagrass (Table 2).

Bahiagrass had less sod tear resistance than the other grasses (Table 3), but its tear resistance appeared to be sufficient for harvest handling. Compost-over-plastic-grown sod had tear resistance values similar to commercially grown sod, with the exception of compost-grown St. Augustinegrass, which had slightly more tear resistance than that grown commercially (Table 3 ).

One week after transplanting, bahiagrass and St. Augustinegrass had more rooting into soil on a weight basis than bermudagrass, although bermudagrass had longer roots (Table 4). Compost-grown sod over plastic had higher root weight in soil than commercially grown sod (Table 4).

At 3 weeks, bahiagrass and bermudagrass had produced more root weight in soil than St. Augustinegrass (Table 4). Root weight for compost-grown turf averaged more than twice that of commercially grown sod, principally because of the high root weight of compost-grown bahiagrass. Bermudagrass and St. Augustinegrass root weights at 3 weeks were unaffected by growing method (Table 4). Turfgrass root lengths were similar at 3 weeks (Table 4).

Sod produced on fertilized compost over a plastic barrier had acceptable quality, appeared to handle well when harvested, had a short grow-in period, and, upon transplanting, rooted extensively into soil. Compared to reported grow-in periods for commercially grown sod (McCarty and Cisar, 1989), the grow-in period for each fertilized compostgrown grass was substantially reduced. However, the grow-in period of 5 months for fertilized compost-grown sod in this experiment was 2.5 times longer than previously reported for 'Argentine' bahiagrass or 'Tifgreen' bermudagrass (Cynodon dactylon sp.) produced on different waste materials (Neel et al., 1978). The longer grow-in period observed in our experiment may have been caused by a delay in turfgrass growth immediately after experiment initiation. During the first weeks after sprigging or sowing, compost-grown turfgrasses displayed symptoms consistent with salinity stress and/or nutrient deficiencies. Six weeks after sprigging, bahiagrass displayed the most severe symptoms, which were a lack of vigor, chlorotic leaf tissue, and a reddish discoloration of leaf blades, leaf blade tips, and leaf blade margins. However, nutrient analyses of bahiagrass leaf tissue from both fertilized and nonfertilized treatments at 6 weeks did not indicate any nutrient deficiencies, toxic levels, or severe nutrient imbalance with the exception of very low $\mathrm{N}$ contents (Table 1). The compost may have immobilized fertil- izer N. According to the manufacturer, the delivered compost had a $\mathrm{C}: \mathrm{N}$ ratio of $40: 1$ (John Nowell, personal communication), which would support this belief. Additionally, high soluble salt content also may have been involved, as the salinity tolerance ranking of the three turfgrasses are: bermudagrass $>$ St. Augustinegrass $>$ bahiagrass (Augustin et al., 1986). However, research documenting the effects of salinity on warmseason turfgrass during establishment is lacking. Research on established warm-season turfgrasses have demonstrated leaf blade growth reductions when turfgrasses were exposed to increasing salinity levels (Ackerson and Younger, 1976; Dudeck and Peacock, 1985; Dudeck et al., 1983).

Soluble salt in the compost was leached even though the black plastic underneath the compost formed an impermeable barrier for downward water movement. Leaching from irrigation and rainfall during this experiment apparently was sufficient to reduce any further potential salinity stresses, as the soluble salt content of compost had decreased substantially at 6 weeks (Table 1).

Although grow-in delay in this experiment may have been related to the medium's initial salinity and $\mathrm{N}$ immobilization, St. Augustinegrass production may have been delayed because of the occurrence of gray leaf spot (Pyricularia grisea) disease during July and August.

Cut-sod piece tear resistance is an important criterion for sod piece handling. Compost-grown sod either performed as well or better than commercially grown sod. The basis of tear resistance for compost-grown and commercially grown sod, however, were noticeably different. Tear resistance of fieldgrown sod is typically a function of stolon/ rhizome/rooting knitting or development. However, for compost-grown sod, tear resistance was more a measure of root development at the interface of compost and the black plastic rather than stolon or rhizome knitting. Commercially grown sod had more stolon/rhizome development due to longer grow-in periods associated with field-grown sod. Also, the fact that commercially grown sod was cut with little soil precluded rooting as a dominant factor for tear resistance of commercially grown sod.

Sod produced on compost over black plastic demonstrated enhanced rooting into soil 1 week after transplanting relative to commercially produced sod. Differences in production and harvesting methods for compostgrown and commercially grown sod probably accounted for the observed differences in compost and commercial sod transplant rooting in our experiment. Growing sod on shallow beds over black plastic provides a production method that does not require severing the sod from its root system when harvesting (Neel et al., 1978). Rooting, in this instance, can occur from the point of the sod piece contact with the soil. With field-cut sod, rooting into soil primarily is initiated from crowns rather than from regrowth of secondary roots (Neel et al., 1978).

The composted solid-waste medium we 
used was suitable for growing turfgrass sod. Producing sod using this medium on plastic near a manufacturer's processing facility could reduce the costs associated with transporting compost and sod to outlets. Recycling waste for sod production may prove to be a viable alternative to the traditional practices of producing sod on agricultural soils and disposing of solid waste in landfills. However, additional research is needed to evaluate the $\mathrm{C}: \mathrm{N}$ ratio of the compost and salinity management before use and also to identify optimal fertilization.

\section{Literature Cited}

Ackerson, R.C. and V.B. Youngner. 1976. Responses of bermudagrass to salinity. Agron. J. 67:678-681.

Ankerman, D. and R. Large. 1990. Agronomy handbook. A \& L Laboratories, Memphis, Tenn.

Augustin, B.J., A.E. Dudeck, and C.H. Peacock. 1986. Saline irrigation of Florida turfgrasses. Florida Coop. Ext. Serv., Univ. of Florida, Inst. of Food and Agr. Sci., Gainesville. Circ. 701.

Beard, J.B. and P.E. Rieke. 1969. Producing quality sod, p. 442-461. In: A.A. Hanson and F.V. Juska (eds.). Turfgrass science. Amer. Soc. Agron. Publ. 14, Madison, Wis.

Cisar, J.L., J.J. Haydu, S.D. Verkade, K.E. Williams, and T.M. Teets. 1988. The 1987 Florida sod survey. Proc. Fla. State Hort. Soc. 101:129131.

Cisar, J.L., L.B. McCarty, and J.J. Haydu. 1992. Sod production in the Everglades agricultural area. In: F. Izuno and A.D. Bottcher (eds.). Water and agriculture in the Everglades. University Presses of Florida, Gainesville. (In press.)

Dudeck, A.E. and C.H. Peacock. 1985. Warmseason turfgrass response to saline irrigation, $\mathrm{p}$. 17-20. In: E. Freeman (ed.). Turfgrass research in Florida. Ornamental Horticulture Dept., Univ. of Florida, Gainesville.

Dudeck, A.E. and C.H. Peacock. 1986. Salinity effects on perennial ryegrass germination, p. 7982. In: E. Freeman (ed.). Turfgrass research in Florida. Ornamental Horticulture Dept., Univ. of Florida, Gainesville.

Dudeck, A.E., S. Singh, C.E. Giordano, T.A. Nell, and D.B. McConnell. 1983. Effects of sodium chloride on Cynodon turfgrasses. Agron. J. 75:927-930.

Florida Department of Environmental Regulation. 1989. Criteria for the production and use of solid waste. Florida Administrative Code Rule 17709. Dept. of Environmental Regulation, Tallahassee, Fla.

ICF, Inc. 1990. Heavy metal concentrations in Agrisoil. ICF. Inc.. Fairfax. Va

Kabbaz, M.R., A.M. Petrovic and L.M. Naylor. 1987. Accelerated sod production utilizing the root impermeable layer system. Agron. Abstr. p. 136.

McCarty, L.B. and J.L. Cisar. 1989. Basic guidelines for sod production in Florida. Florida Coop. Ext. Serv., Inst. of Food and Agr. Sci., Univ. of Florida, Gainesville. Bul. 260.

McCloud, D.E. 1955. Water requirements of field crops in Florida as influenced by climate. Proc. Soil Sci. Soc. Fla. 15:165-172.

Neel, P.L., E.O. Burt, P. Busey, and G.H. Snyder. 1978. Sod production in shallow beds of waste materials. J. Amer. Soc. Hort. Sci. 103:549-553.

Nelson, D.W. and L.E. Sommers. 1982. Total carbon, organic carbon, and organic matter, $p$. 571-573. In: A.L. Page, R.H. Miller, and D.R. Keeney (eds.). Methods of soil analysis. Amer.
Soc. Agron. and Soil Sci. Soc. Amer., Madison, Wis.

SAS. 1985. SAS/STAT guide for personal computers, version 6 ed. SAS Inst., Inc., Cary, N.C.
Snyder, G.H., C.A. Sanchez, and J.S. Alrichs. 1989. DRIS evaluation of the nutrient status of bahia and St. Augustine turfgrasses. Proc. Fla. State Hort. Soc. 102:133-137. 